\title{
Anti-apoptotic and oncogenic properties of the dsRNA-binding protein of vaccinia virus, E3L
}

\author{
Maria Angel García ${ }^{1}$, Susana Guerra ${ }^{1}$, Jesús Gil ${ }^{1,2}$, Victoria Jimenez ${ }^{1}$ and Mariano Esteban*,1 \\ ${ }^{1}$ Department of Molecular and Cellular Biology, Centro Nacional de Biotecnología, Consejo Superior de Investigaciones Cientificas, \\ (CSIC), Campus Universidad Autónoma, 28049 Madrid, Spain
}

\begin{abstract}
The vaccinia virus (VV) E3L gene encodes a dsRNA binding protein that inhibits activation of the IFNinduced, dsRNA-dependent protein kinase, (PKR), the 2-5A synthetases/RNase $L$ system and other dsRNA dependent pathways, thus leading to efficient VV replication. To analyse E3L effects over cellular metabolism in a virus-free system, we have generated stable mouse 3T3 cell lines expressing E3L. Expression of E3L in NIH3T3 cells results in inhibition of eIF-2 $\alpha$ phosphorylation and $I \kappa B \alpha$ degradation in response to dsRNA. Antiviral responses induced by IFN- $\alpha / \beta$ were partially impaired in 3T3-E3L cells, as determined by a viability assay upon VSV infection. E3L expression also confers resistance to dsRNA-triggered apoptosis. Interestingly, cells expressing E3L grew faster than control cells, and showed increased expression of cyclin $A$ and decreased levels of $\mathrm{p}^{\mathrm{Kip} 1}$. E3L cooperated with H-ras in a focus formation assay, and NIH3T3 E3L cells formed solid tumors when injected in nude mice. Overall, our findings reveal that interference of $\mathrm{E} 3 \mathrm{~L}$ protein with several cellular pathways, results in promotion of cellular growth, impairment of antiviral activity and resistance to apoptosis.

Oncogene (2002) 21, 8379-8387. doi:10.1038/sj.onc. 1206036
\end{abstract}

Keywords: E3L; vaccinia virus; dsRNA; PKR; tumor; apoptosis

\section{Introduction}

Virus infected cells are stimulated to produce and secrete interferons (IFNs). The production of IFNs is triggered by dsRNA accumulation upon viral infection (Jacobs and Langland, 1996). Once secreted, IFN initiates a signal transduction pathway that commences by the recognition of a cell surface receptor and culminates with targeted gene expression (Stark et al.,

*Correspondence: M Esteban, Centro Nacional de Biotecnología, CSIC, Campus Universidad Autónoma, 28049 Madrid, Spain;

E-mail: mesteban@cnb.uam.es

${ }^{2}$ Current address: Wolfson Institute for Biomedical Research, University College of London, Gower Street, London WC1E 6BT, UK

Received 19 August 2002; revised 5 September 2002; accepted 11 September 2002
1998). More than 100 different genes have been identified as being IFN-induced, including genes that trigger apoptosis, modulate immune responses and establish an antiviral state at the host cell level (Der et al., 1998). In addition, IFNs are potent antitumor agents (Stark et al., 1998). The antiviral response triggered by IFNs is a complex process involving several pathways. Even mouse with three antiviral enzymes modified by target recombination, are still able to establish a protective state in response to IFN priming (Zhou et al., 1998). Interestingly, at least two major antiviral pathways induced by IFNs are also activated by dsRNA. One involves endoribonuclease L (RNase L), an IFN-inducible enzyme present in mammalian cells that is a component of the $2-5 \mathrm{~A}$ system, together with dsRNA-activated 2-5A synthetases (reviewed in Rebouillat and Hovanessian, 1999; Sen and Lengyel, 1992). The other pathway is triggered by PKR, a serine-threonine kinase (Meurs et al., 1990; for review Clemens and Elia, 1997) which is activated by dsRNA binding. PKR controls different cellular processes such as cell growth (Chong et al., 1992), differentiation (Petryshyn et al., 1984), apoptosis (Lee and Esteban, 1994; Der et al., 1997), stress response (Tan and Katze, 1999; Williams, 1999) and also exerts antiviral (Lee and Esteban, 1993; Lee et al., 1996) and antitumor activities (Koromilas et al., 1992; Meurs et al., 1993). Upon activation, PKR inhibits initiation of translation by phosphorylating eIF-2 $\alpha$, the alpha subunit of the eukaryotic initiation factor 2 (Levin and London, 1978), and also regulates activation of several transcription factors such as IRF-1, p53, and NF- $\kappa$ B (Kumar et al., 1997; Cuddihy et al., 1999a,b). In addition, dsRNA induces activation of other transcription factors such as IRF-3 that is also involved in virus-induced apoptosis, (Heylbroeck et al., 2000) and c-Jun (Chu et al., 1999). Overall, dsRNA triggers the induction of more than a hundred genes (Geiss et al., 2001), some of them with ability to modulate cell growth such as p56 (Guo et al., 2000).

Many viruses encode direct inhibitors of the IFNtransduction pathway or specific inhibitors of IFNinduced proteins to avoid deleterious effects triggered by these cytokines (Smith, 1994; Smith et al., 1997). In most cell lines tested vaccinia virus (VV) is relatively resistant to the antiviral effects of IFN (Paez and Esteban, 1984). In addition, VV is able to rescue the replication of IFN-sensitive viruses, such as vesicular 
stomatitis virus (VSV) and encephalomyocarditis virus (EMCV) upon coinfection (Paez and Esteban, 1984). To counteract IFN action, VV encodes secreted receptors for IFNs (Symons et al., 1995; Alcami and Smith, 1995) and at least two proteins, K3L and E3L, that have the ability to inhibit IFN-induced pathways. $\mathrm{K} 3 \mathrm{~L}$ is a PKR pseudosubstrate and E3L is a high affinity dsRNA-binding protein (Davies et al., 1993). The E3L gene of VV encodes two proteins, p25 and p20 (Watson et al., 1991) that are expressed early in infection (Yuwen et al., 1993) and are incorporated in the virions of VV (Murcia-Nicolas et al., 1999). E3L is a host range gene, necessary for efficient VV replication in several cell lines (Beattie et al., 1995) and is required for VV pathogenesis (Brandt and Jacobs, 2001). The important role of E3L in the viral-defense mechanism against IFNs is highlighted by several experimental findings. A VV mutant lacking $\mathrm{E} 3 \mathrm{~L}(\mathrm{VV} \Delta \mathrm{E} 3 \mathrm{~L})$ is sensitive to the antiviral effects of IFN (Beattie et al., 1995) and induces apoptosis in HeLa cells (Lee and Esteban, 1994). E3L has also been shown to be an inhibitor of PKR both in vitro and in vivo (Chang et al., 1992), due to dsRNA sequestration and direct binding to PKR (Romano et al., 1998; Sharp et al., 1998). E3L has also been shown to inhibit the 2-5 A system (Rivas et al., 1998) and to prevent phosphorylation and subsequent activation of IRF3 and IRF7 (Smith et al., 2001).

Because of the multiple biological effects of E3L over IFN and dsRNA-triggered pathways, it was of interest to examine the consequences of $\mathrm{E} 3 \mathrm{~L}$ expression in mammalian cells, in the absence of other VV functions. To this aim, we generated mouse NIH3T3 cell lines constitutively expressing E3L protein of VV. E3L expression was able to inhibit eIF- $2 \alpha$ phosphorylation and $\mathrm{I} \kappa \mathrm{B} \alpha$ degradation in response to dsRNA. Different parameters such as interference with antiviral activities of IFN, effect on apoptosis and cell growth have been evaluated. Overall, E3L expression confers antiapoptotic and oncogenic properties to NIH3T3 cells, highlighting the importance of dsRNA-activated pathways in cell metabolism.

\section{Results}

Generation of $3 T 3$ cells expressing functional E3L protein of $V V$

In order to directly analyse the role of E3L protein on cellular metabolism, we constructed a plasmid encoding the E3L protein under the control of a CMV promoter (pCINEO-E3L), and generated cells stably expressing this protein. Expression of the E3L protein was confirmed by Western blot analysis (Figure 1a). The molecular mass of the E3L protein in Western blots was the same as the viral protein synthesized during VV infection (left lane). Based upon these results we selected the cell line in which the viral protein was stably produced. As controls, we used parental cells and cell lines transfected with the empty vector. To examine potential biological effects of E3L expression, we analysed eIF- $2 \alpha$ phosphorylation in response to $\mathrm{pIC}$ (a synthetic dsRNA polymer) treatment of these cell lines. As expected, E3L expression resulted in inhibition of eIF- $2 \alpha$ phosphorylation in response to dsRNA treatment (Figure 1b).

The main role of E3L during $\mathrm{VV}$ infection is to inhibit several antiviral pathways. To further validate that E3L was functional in NIH3T3 cells, we measured IFN-induced resistance to VSV infection. To this end, cells were pre-treated for $16 \mathrm{~h}$ with different doses of IFN $\alpha / \beta$, infected with VSV, and at 36 h.p.i. cell viability was determined. IFN protected NIH3T3 cells and control clones against VSV-induced cytopathic effects in a manner dependent on the dose, reaching $100 \%$ protection at an IFN dose of 100 units or higher (Figure 1c). In the case of NIH3T3-E3L cells, protection by IFN was reduced to $60-70 \%$. Similar results were obtained in three independent experiments and using independent clones. These findings indicate that E3L protein expressed in NIH3T3 is fully functional.

\section{Effect of E3L expression over dsRNA-dependent I $\kappa B \alpha$ degradation}

DsRNA triggers the activation of multiple signal transduction cascades including the NF- $\kappa \mathrm{B}$ pathway. To analyse the effect of E3L on NF- $\kappa \mathrm{B}$ activation we determined the degradation of $\mathrm{I} \kappa \mathrm{B} \alpha$ in response to dsRNA in NIH3T3-E3L and control cells. Cells were treated with either pIC or LPS (Figure 2). Both 3 T3 cells and 3T3-Neo cells suffered degradation of $\mathrm{I} \kappa \mathrm{B} \alpha$ after $1 \mathrm{~h}$ post-treatment with pIC. Degradation of $\mathrm{I} \kappa \mathrm{B} \alpha$ was not detected in 3T3-E3L cells exposed to the same pIC treatment but rather $\mathrm{I} \kappa \mathrm{B} \alpha$ levels increased with time as a consequence of resynthesis. No significant differences in $\mathrm{I} \kappa \mathrm{B} \alpha$ degradation were observed between the different cell lines subjected to LPS treatment (Figure 2).

\section{Expression of E3L inhibits dsRNA-induced apoptosis}

DsRNA triggers apoptosis through activation of several different pathways (Lee and Esteban, 1994; Der et al., 1997; Díaz-Guerra et al., 1997; Zhou et al., 1997; Castelli et al., 1997). To evaluate if E3L expression confers resistance to NIH3T3 cells to apoptosis induced by dsRNA, semiconfluent cells were treated with pIC as previously described (Der et al., 1997). Viability of cells was analysed by staining using vital dye. Figure 3 demonstrates that NIH3T3-E3L cells are significantly protected from pIC-induced apoptosis compared with control cells. Similar results were obtained in three independent experiments, and using independent clones.

\section{Growth properties of 3T3-E3L cell lines}

Expression of inactive PKR mutants or of several PKR inhibitors has been shown to promote cell growth (Koromilas et al., 1992; Meurs et al., 1993; Tang et al., 


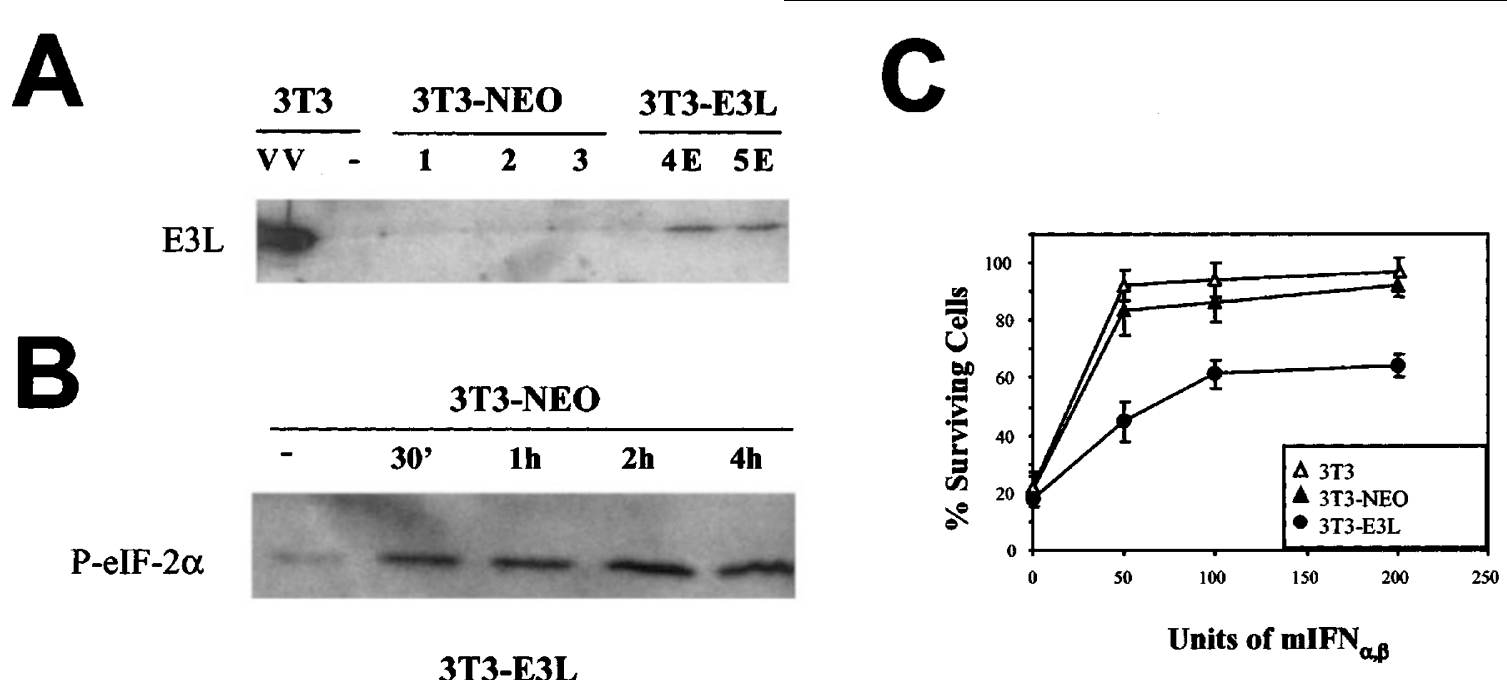

3T3-E3L

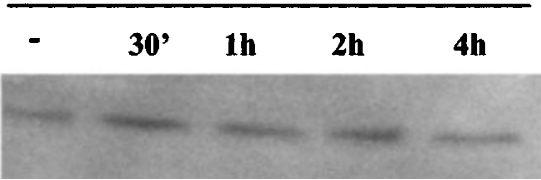

Figure 1 Generation of NIH3T3 cells stably expressing E3L protein from vaccinia virus. (a) Presence of E3L protein was detected in stable cell lines transfected with pCINEO-E3L by Western blotting using specific E3L polyclonal antibodies. (b) Levels of eIF2 $\alpha$ phosphorylation after pIC treatment were evaluated by immunoblot- analysis using phosphorylation-state specific antibodies. (c) E3L expression partially inhibits antiviral effects exerted by IFNs. 3T3 cell lines seeded in six well plates were treated for $16 \mathrm{~h}$ with the indicated doses of murine IFN $\alpha / \beta$ and, thereafter, cells were infected with 500 p.f.u./well of VSV. Cell viability was measured at 36 hpi by staining with crystal violet and the cell-associated dye was quantified as described in Materials and methods. Each time point was determined in duplicate

1999; Gale et al., 1999). Hence, we evaluated the effect of E3L expression on growth properties of NIH3T3 cells. Growth of 3T3-E3L cells was more rapid than control cells, as shown with two independent clones (Figure 4a), reaching higher cell densities (data not shown). As a further confirmation of enhanced growth of E3L-expressing cells, we observed an accelerated entry into $\mathrm{S}$ phase after starvation and restimulation with serum (Figure 4b). Progression from $G_{1}$ to $S$ phase in mammalian cells is regulated through accumulation of cyclins D, E and A, which bind to and activate different Cdks (review, Sherr, 1994). To analyse the molecular basis of the enhanced growth properties of E3L-expressing cell lines, we performed RNase protection assays. Cyclin D1 and D2 expression was slightly downregulated in cells expressing E3L protein (Figure 4c). However, cyclin A, involved in S phase entry, was upregulated in NIH3T3-E3L cells. This is consistent with the enhanced $\mathrm{S}$ phase entry observed in these cells.

The cell cycle is tightly regulated by modification of cdk activity by different cdk inhibitors (Sherr and Roberts, 1995). Thus, we performed Western blots against the cdk inhibitors, p16 $6^{\text {Ink4a }}, \mathrm{p} 21^{\text {Cip } 1}$ and $\mathrm{p} 27^{\mathrm{Kip} 1}$. In the absence of E3L expression, levels of $\mathrm{p} 16^{\text {Ink4a }}$ and $\mathrm{p} 21^{\mathrm{Cip} 1}$ were almost undetectable and remained constant in the different cell lines (data not shown). However, as shown in Figure 4d, 3T3-E3L cells showed decreased levels of $\mathrm{p} 27^{\mathrm{Kip} 1}$ as compared with the 3T3-p-NEO counterparts. These findings suggest that E3L can promote cell growth in a virusfree environment via interference with dsRNA-triggered pathways.

\section{Oncogenic properties of E3L protein expression}

To further investigate the transforming potential of the E3L protein, we examined the ability of E3L expressing cells of growing in soft agar. As shown in Figure 5a, expression of E3L enabled anchorageindependent growth of 3T3 cells, in a similar way to what happened when cells were expressing H-ras v12 as a positive control. Next we analysed E3L ability to cooperate with H-ras in focus formation. To this end, NIH3T3 cells were transfected with the vectors indicated in Figure 5b. No foci were observed in cells transfected with the pCINEO plasmid or with pCINEO-E3L alone. However, a significant number of foci were detected upon expression of H-ras (Figure $5 \mathrm{~b})$. When the E3L plasmid was cotransfected with the $\mathrm{H}$-ras plasmid, the number of foci was almost doubled, suggesting that VV E3L protein cooperated with $\mathrm{H}-$ ras in this process. Noteworthy, this experiment was performed using a polyclonal cell population, indicating that clonal effects do not account for the result.

Since overexpression of PKR inhibitors, such as p58 and TRBP produced tumor formation in nude mice (Meurs et al., 1993; Barber et al., 1994; Tang et al., 1999; Benkirane et al., 1997) we decided to examine if E3L overexpression could also produce tumors. 
A

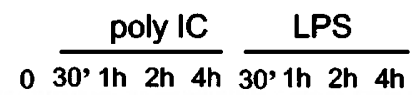

3 T3

0 30' 1h $2 \mathrm{~h} 4 \mathrm{~h} 30$ ' 1h $2 \mathrm{~h} 4 \mathrm{~h}$

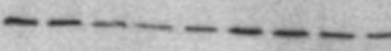

$I_{k} B \alpha$

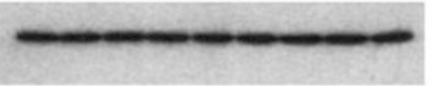

$\beta$-actin

B

$\frac{\text { poly IC }}{30^{\prime} \text { ih } 2 \mathrm{~h} 4 \mathrm{~h}} \frac{\text { LPS }}{30^{\prime} \text {, } \mathrm{h} 2 \mathrm{~h} 4 \mathrm{~h}}$

\section{T3-NEO}
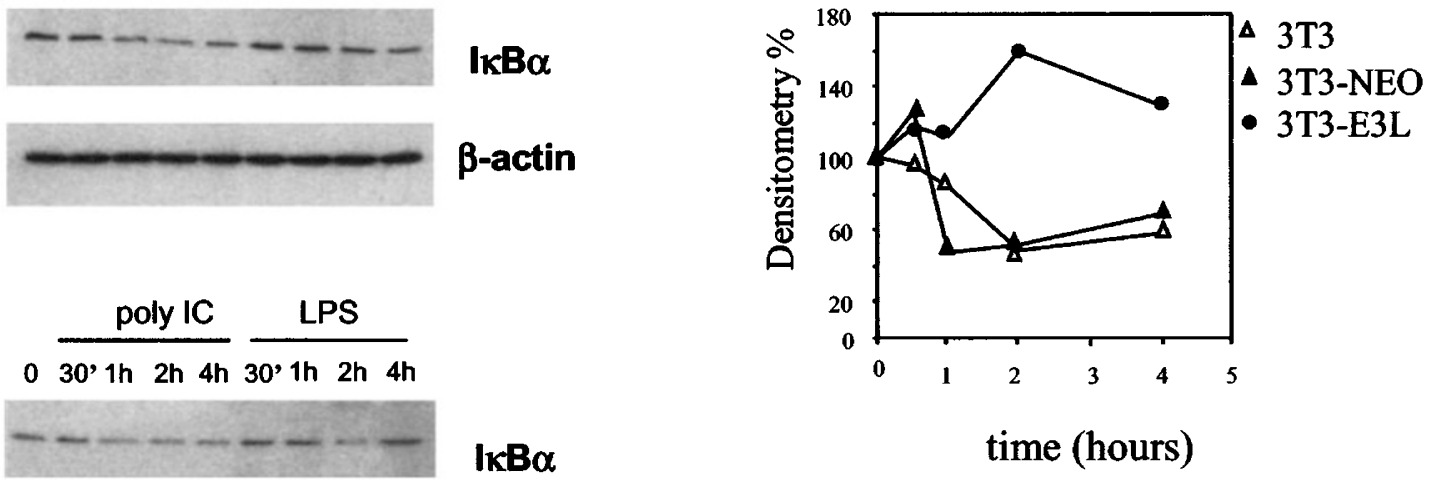

$\mid \kappa B \alpha$

time (hours)

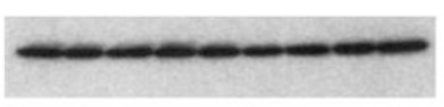

\section{B-actin}
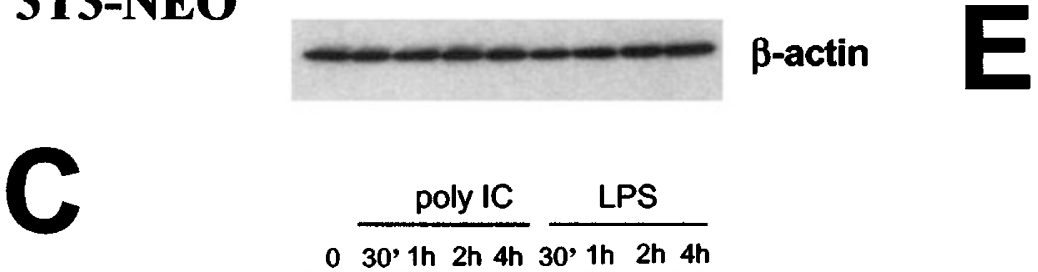

3T3-E3L

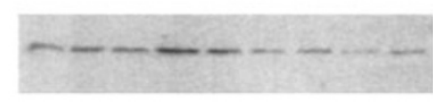

IKB $\alpha$

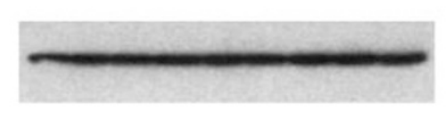

$\beta$-actin

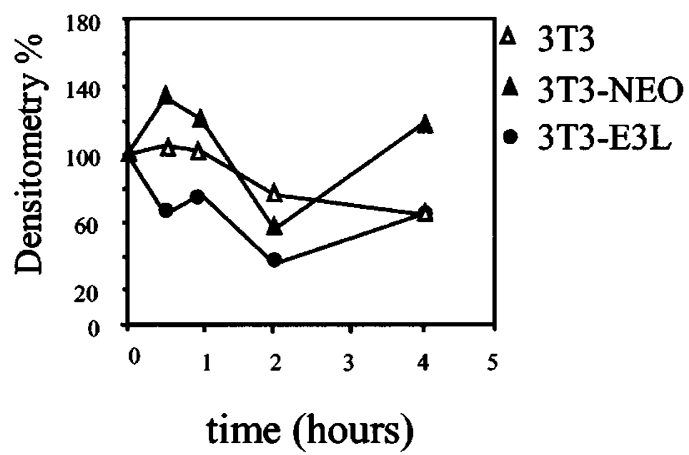

Figure 2 Effect of E3L expression on LPS and pIC-triggered $\mathrm{I} \kappa \mathrm{B} \alpha$ degradation. NIH3T3 (a), 3T3-NEO (b) or 3T3-E3L cells (c) were treated with $20 \mu \mathrm{g} / \mathrm{ml} \mathrm{pIC}$ or $5 \mathrm{ng} / \mathrm{ml}$ LPS. At indicated times, cells were lysed and degradation of $\mathrm{I} \kappa \mathrm{B} \alpha$ and $\beta$-actin level were analysed by Western blotting. Bands were scanned by densitometry and intensity at time 0 for each cell line was taken as $100 \%$. Quantitative analyses of $\mathrm{I} \kappa \mathrm{B} \alpha$ degradation in response to pIC (d) or LPS treatment (e) are shown

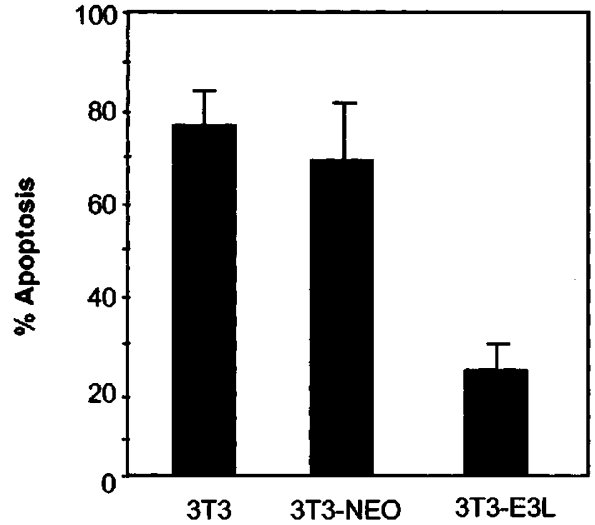

Figure 3 NIH3T3 E3L cells are resistant to pIC-induced apoptosis. Semi confluent $3 \mathrm{~T} 3$ cell lines were starved for $2 \mathrm{~h}$ and transfected with $\mathrm{pIC}(20 \mu \mathrm{g} / \mathrm{ml})$, in the presence of actinomycin D (50 ng/ml), using Lipofectamine (Gibco) following the supplier's instructions. Apoptosis was measured at $24 \mathrm{~h}$ after treatment as described in the Materials and methods

NIH3T3, NIH3T3-Neo cells and NIH3T3-E3L cells were injected into the right flank of four nude mice and mice were monitored for tumor formation (Figure 5c). While no tumors were observed in the control groups, three of the four mice inoculated with E3L-3T3 cells developed tumors after 7 weeks postinoculation. Tumors had typical histological features of fibrosarcoma (data not shown) exhibiting pleiomorphic spindle-shaped cells with hiperchromatism and a high mitotic rate and were positive for E3L expression as detected for RT-PCR (Figure 5d). These in vitro and in vivo results suggest that $\mathrm{E} 3 \mathrm{~L}$ protein of $\mathrm{VV}$ has oncogenic potential.

\section{Discussion}

Many different viruses encode inhibitors of IFNs in order to counteract the antiviral effects exerted by these cytokines. These inhibitors directly sequester IFNs, interfere with IFN-induced signaling or act against IFN-induced proteins (Smith et al., 1997; Smith, 1994; Symons et al., 1995; Alcami and Smith, 1995). Several viruses like $\mathrm{VV}$, influenza and reovirus encode for dsRNA-binding proteins (Beattie et al., 1996; Chang et 

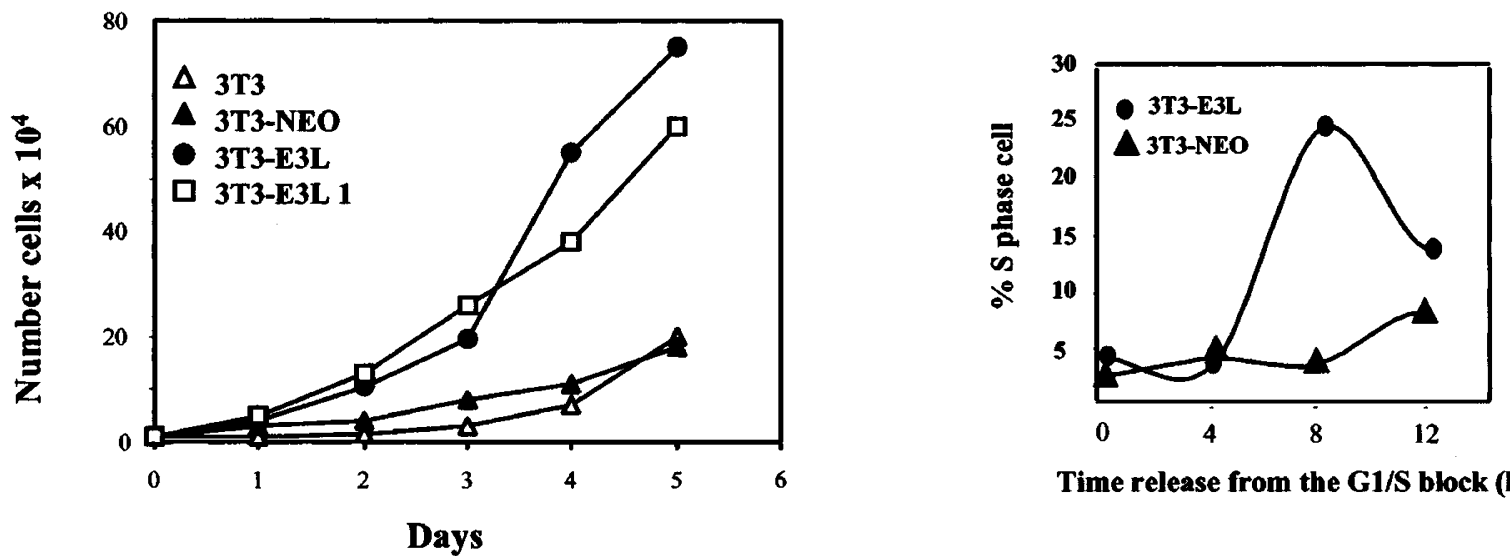

Time release from the G1/S block (h)
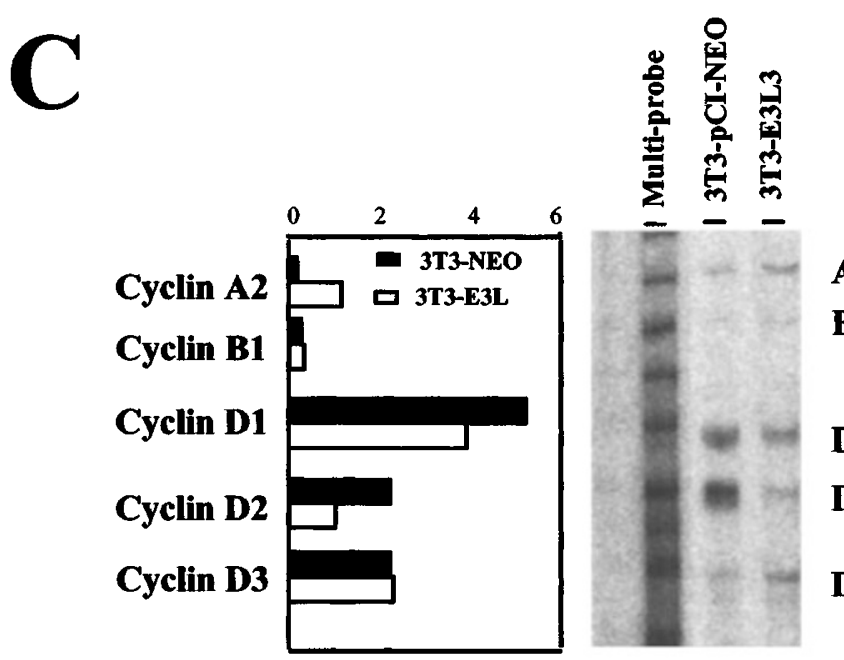

A2

B1

D1

D2

D3

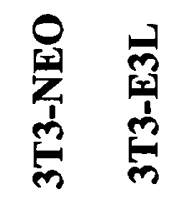

p27

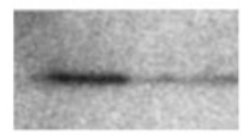

b-actin

Figure 4 Growth properties of NIH3T3 cell expressing E3L. (a) 3 T3 cell lines were seeded (10000 cells/well) in 12-well plates in DMEM supplemented with $10 \%$ FCS. Medium was changed after 2 days, and every day cell numbers were counted using a hemocytometer. Each growth curve was performed at least twice, and each time point was determined in triplicate. (b) Re-entry into S phase was determined after serum deprivation of 3T3-NEO (triangles) and 3T3-E3L cells (circles). (c) Total RNA from 3T3-NEO and 3T3-E3L cells were analysed by RNase protection with radiolabeled probes specific for cyclins at $6 \mathrm{~h}$ post synchronization. The protected samples were separated by denaturing gel electrophoresis and quantified using a STORM Phosphorimager. (d) $100 \mu \mathrm{g}$ of total proteins were separated by SDS-PAGE, transferred to nitrocellulose and immunoblotted with antibodies against p27 ${ }^{\mathrm{Kip} 1}$ (upper panel) and $\beta$-actin (lower panel)

al., 1992; Lu et al., 1995). These dsRNA-binding proteins are effective inhibitors of the IFN antiviral response. They inhibit IFN production and directly block the action of antiviral proteins such as RNase L and PKR (Chang et al., 1992; Rivas et al., 1998). The VV E3L protein is one of these dsRNA-binding proteins with a key role in VV replication. The biological role of E3L has been studied using various approaches including the generation of VV mutants with selective deletions of the gene and complementation of the phenotype of the virus in transient or through the generation of recombinant viruses (Chang et al., 1992; Brandt and Jacobs, 2001). In this investigation, we have taken an alternative approach to define the role of E3L on cellular function in the absence of VV. We have generated cell lines constitu- tively expressing the E3L protein and demonstrated that expression of this protein has a significant impact on cellular functions even in the absence of virus infection. Both eIF- $2 \alpha$ phosphorylation and $\mathrm{I} \kappa \mathrm{B} \alpha$ degradation are inhibited in NIH3T3-E3L cells in response to dsRNA. The fact that activation of two PKR-dependent signaling pathways is impaired in these cells highlights the value of the system.

We also found that 3T3-E3L cells are more resistant to the antiviral effects of IFN than control cells. The most likely explanation for IFN resistance is partial interference with multiple dsRNA-dependent pathways. PKR, the $2-5 \mathrm{~A}$ system, IRF3, IRF7 or p56 among others have been shown to be activated by dsRNA and have antiviral properties (Meurs et al., 1990; Smith et al., 2001; Guo et al., 2000). The idea of multiple 
$\mathbf{A}$

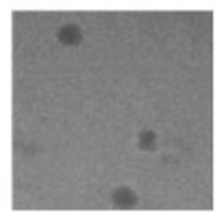

3T3-H ras

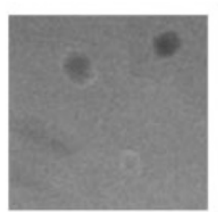

3T3-E3L

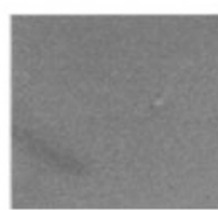

3T3-NEO
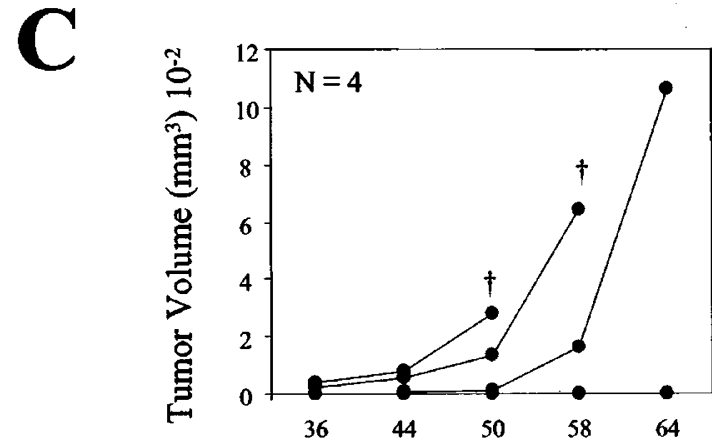

Time postcell inoculation (days)

B

D

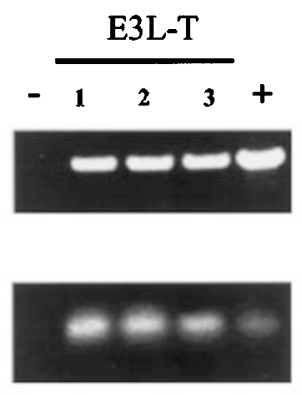

E3L

HPRT

Figure 5 E3L confers tumorigenic properties to NIH3T3 cells. (a) Anchorage-independent cell growth was analysed by growing 10000 cells in soft agar during 3 weeks. Representative pictures are shown. (b) E3L expression cooperates with H-ras oncogene in focus formation. NIH3T3 cells were transfected with either $5 \mu \mathrm{g}$ of pCINEO, $5 \mu \mathrm{g}$ of pCINEO-E3L, $5 \mu \mathrm{g}$ of pAL8 H-ras, or $5 \mu \mathrm{g}$ of pCINEO-E3L and $5 \mu \mathrm{g}$ of pAL8 H-ras. A total of $15 \mu \mathrm{g}$ of DNA were used per transfection using the required amounts of pCINEO plasmid. (c) E3L expression induces tumors in nude mice. Nude mice were injected with $3 \times 10^{6}$ NIH3T3-NEO or NIH3T3-E3L cells. Tumor formation was monitored and the volume measured weekly. (d) Analysis of E3L expression by RTPCR in tumors is shown. HPRT amplification was used as an internal control

antiviral pathways needing to be suppressed simultaneously is supported by the fact that VV $\Delta$ E3L replication is not fully recovered in $\mathrm{PKR}^{0 / 0}$, in $\mathrm{RNase}$ $\mathrm{L}^{\mathrm{O} / 0}$ cells, or even in triple knockout mice defective in Mx, PKR and RNAse L (Rivas et al., 1998; Xiang et al., 2002).

DsRNA is a potent inducer of apoptosis (Kibler et al., 1997) and can act by recognition of Toll-like receptors (Alexopoulou et al., 2001). Expression of E3L resulted in enhanced resistance to cell death upon pIC-treatment, consistent with a general inhibition of dsRNA-dependent pathways. Multiple dsRNA-dependent proteins, such as PKR, RNaseL or IRF-3 have been shown to be involved in apoptosis induction in response to stimuli such as serum deprivation, treatment with TNF- $\alpha$, LPS, or virus infection (Der et al., 1997; Zhou et al., 1997; Srivastava et al., 1998). Thus, expression of E3L protein modulates the activity of several dsRNA-binding proteins and protects cells from cell death at various levels.

Expression of inactive PKR mutants, or PKR inhibitors results in promotion of cell growth (Koromilas et al., 1992; Meurs et al., 1993; Tang et al., 1999; Park et al., 1994; Gale et al., 1999). Cell growth is also controlled by other dsRNA-dependent pathways such as the 2-5 A system (Zhou et al., 1997) or p56 targeting of eIF3 (Guo et al., 2000). In this context, IRF3 is activated by UV and anticancer drugs, suggesting a possible role as a tumor suppressor (Kim et al., 1999). Hence, we analysed the effect of E3L expression on cell growth. Even when the levels of E3L expression in NIH3T3-E3L cells were lower compared to VV-infected cells, these cells proliferated more rapidly than control cells. When liberated from starvation 3T3-E3L cells entered the S phase before control cells, as a result of enhanced cyclin A levels. In addition, when we analysed expression levels of several cdk inhibitors by Western blotting, p2 $7^{\mathrm{Kip} 1}$ levels were diminished in NIH3T3-E3L cells. Interestingly, p2 $7^{\text {Kip1 }}$ is upregulated at a posttranscriptional level during IFN-induced cell cycle arrest (Sangfelt et al., 1999). Cells expressing cellular and viral PKR inhibitors such as TRBP, p58 $8^{\mathrm{IPK}}$, NS5A or inactive mutants of PKR, have oncogenic properties and produce solid tumors when injected into nude mice (Meurs et al., 1993; Benkirane et al., 1997; Tang et al., 1999; Ghosh et al., 1998). PKR is required for cell growth control and is a potential tumor suppressor (Jagus et al., 1999; Williams, 1999), despite the fact that $\mathrm{PKR}^{0 / 0}$ mice do not show increased tumor rates (Yang et al., 1995). 
Since VV E3L is an inhibitor of PKR and of other dsRNA-dependent pathways and, as shown here, also promotes cell growth, it was not surprising to find that E3L induces transformation under certain conditions. Despite E3L by itself was not able to induce foci formation, it can cooperate with $\mathrm{H}$-ras and induce anchorage-independent growth by itself. In addition, when injected into nude mice, NIH3T3-E3L cells generated solid tumors, further supporting the importance of dsRNA-dependent pathways in controlling cell growth and tumor formation. It should be noted that VV does not induce transformation in cultured cells nor in animals probably due to cell destruction as a cause of virus infection and by the strong activation of the immune system. Under those conditions, the virus E3L protein, which is an early product might not be capable of triggering cell transformation.

In conclusion, in this investigation we have demonstrated the effect of constitutive expression of the VV dsRNA-binding protein E3L in mouse NIH3T3 cells. E3L expressing cell lines exhibit increased resistance to the antiviral effects of IFNs $\alpha / \beta$ and decreased cell death in response to pIC treatment. Noteworthy, we present evidence that the $\mathrm{E} 3 \mathrm{~L}$ protein of $\mathrm{VV}$ has oncogenic properties, both in vitro and in vivo. These observations establish a framework for future work using ectopic expression of E3L protein in cell lines or organisms to study the biological effect of interfering with dsRNA signaling pathways and to determine the potential benefits as a result of increased cell viability or enhanced expression of foreign proteins.

\section{Materials and methods}

\section{Materials}

G-418 (Geneticin) was purchased from Invitrogen. Crystal Violet, actinomycin D and polyriboinosinic polyribocytidilic acid (pIC) were from Sigma. Polyclonal antibody recognizing E3L proteins was kindly provided by Bertram L Jacobs (Arizona State University, AZ, USA).

\section{Plasmid constructions}

Plasmid pCINEO-E3L was generated by cloning a HindIII/ EcoRV fragment of pcDNA-E3L (Rivas et al., 1998) treated with Klenow enzyme (Roche) in pCINEO (Promega) previously digested with $S m a$ I restriction enzyme. Plasmid pAL8-H ras was generously provided by Mariano Barbacid (CNIO, Spain).

\section{Cells}

Mouse NIH3T3 cells were grown in DMEM supplemented with $10 \%$ calf serum (CS). Cells were cultured at $37^{\circ} \mathrm{C}$ in $5 \%$ $\mathrm{CO}_{2}$ in DMEM medium containing foetal calf serum and antibiotics. For the generation of $3 \mathrm{~T} 3$ cell lines containing the E3L gene, cells were transfected with $10 \mu \mathrm{g}$ of pCINEO-E3L or with the same amount of a control plasmid pCINEO, using the calcium phosphate transfection method (Current Protocols in Molecular Biology). After 2 days of incubation in the presence of $500 \mu \mathrm{g} / \mathrm{ml} \mathrm{G} 418$ (Geneticin; Invitrogen), cells were trypsinized, diluted, plated in medium containing the drug at $700 \mu \mathrm{g} / \mathrm{ml}$ and surviving colonies were cloned and further expanded in the presence of $700 \mu \mathrm{g} / \mathrm{ml}$ of G418.

\section{$R T-P C R$ analysis}

Total mRNA was purified from aseptically removed tumors. Essentially, identical pieces of tumor from three mice were homogenized in extraction buffer using an Ultraturrax T8 mechanical homogenizer (Janke and Kunkel, Staufen, Germany). Clear lysates were used as the source for mRNA purified using RNA Wiz purification kit (Ambion) following the instruction of the manufacturer. This method is based on nucleic acid extraction with guanidinium thiocyanate and purification with oligo (dT)-cellular chromatography in a spin column. Equal amounts of mRNA were reverse-transcribed and amplified by the polymerase chain reaction using the Superscript one-step RT-PCR system (GIBCO-BRL) as indicated by the supplier. The primers used for the detection of mRNA from E3L were 5'-CCG GAT CCC GAT GTC TAA AAT CTA TAT CG-3' and $5^{\prime}-\mathrm{GCG}$ GTA CCC CTC AGA ATC TAA TGA TGA CG-3' that amplified a 593 bp fragment. Control primers used for the detection of mRNA from the HPRT housekeeping gene (5'-GTT GGA TAC AGG CCA GAT TTG TTG-3' and 5'-GAT TCA ACT TGC GCT CAT CTT AGG C-3') amplify a 163 bp fragment. Amplification conditions (25 cycles for HPRT and 30 cycles for E3L) were checked to be in the exponential phase of PCR. Amplification reactions were made using a PTC-100 thermocycler (MJ Research) and analysed by $2 \%$ agarose gel electrophoresis.

\section{FACS analysis}

To analyse entry into S phase, 3T3-NEO and 3T3-E3L cells were serum deprived for $48 \mathrm{~h}$. Cultures were induced to enter the cell cycle by the addition of DMEM supplemented with $10 \%$ CS. After $0,4,8$, and $12 \mathrm{~h}$ the cell cycle state was analysed by PI staining and FACS (Xu et al., 2002).

\section{Immunoblotting}

For E3L Western blot analysis, total cell extracts were fractionated by gel electrophoresis (SDS-PAGE) and proteins were transferred to nitro-cellulose paper. Filters were incubated with E3L antibodies and expression detected using ECL Western blotting reagents (Amersham). For p27 kipl immunoblotting, $50 \mu \mathrm{g}$ of total cell protein was loaded per line and amounts confirmed by Western blot with antibodies to $\beta$-actin. Levels of expression were evaluated after exposure of filters to Kodak X-OMAT film.

\section{Antiviral activity assay}

Confluent cells grown in six-well plates were treated for $12-$ $16 \mathrm{~h}$ with the indicated amounts of murine IFN $\alpha / \beta$ (Lee Biomolecular; specific activity $10^{8}$ units $/ \mathrm{mg}$ ). After IFN treatment, cells were infected with vesicular stomatitis virus (VSV) at 500 p.f.u./well and at 36 h.p.i. cells were washed with PBS, fixed in $10 \%$ formalin, and rinsed with distilled water. Cells were stained with $0.1 \%$ crystal violet for $30 \mathrm{~min}$, rinsed extensively, and dried. Cell-associated dye was extracted with $2 \mathrm{ml} 10 \%$ acetic acid. Aliquots were diluted $1: 4$ with $\mathrm{H}_{2} \mathrm{O}$, transferred to 96 -well microtiter plates, and the optical density at $590 \mathrm{~nm}$ (OD 590) was determined. Values were normalized to the optical density at day 0 for the appropriate cell clone. Each time point within an experiment was determined in duplicate. 


\section{Apoptosis assay}

The cell death detection enzyme-linked immunosorbent assay (ELISA) kit (Roche) was used according to the manufacturer's instruction. This assay is based on the quantitative sandwich enzyme immunoassay principle and uses mouse monoclonal antibodies directed against DNA and histones to estimate the amount of cytoplasmic histone-associated DNA.

\section{Formation of tumors in nude mice}

Female 4-6 week old nude mice were inoculated subcutaneously in the right flank with $3 \times 10^{6} 3$ T3-E3L cells resuspended in $0.1 \mathrm{ml}$ PBS. Mice were checked daily for tumor formation. Mice were sacrificed and tumor specimens analysed for E3L mRNA and examined histologically.

\section{Focus formation assay}

NIH3T3 cells were plated in DMEM containing $10 \%$ calf serum at a density of $1 \times 10^{6}$ cells $/ 100 \mathrm{~mm}$ plate. After $14 \mathrm{~h}$ incubation, the cells were transfected with pCINEO alone, with pCINEO-E3L, with pATL-Ras H or with pCINEO-E3L and pATL-Ras $\mathrm{H}$ using the jepPEITM reactive (Genycell). The total amount of transfected DNA was fixed to $15 \mu \mathrm{g}$ with pCINEO plasmid DNA as a carrier. At $24 \mathrm{~h}$ posttransfection, the medium was changed with DMEM containing $10 \%$ calf serum, and at $48 \mathrm{~h}$ post-transfection cells were split at 4:1 ratio and cultured with DMEM containing 5\% calf serum. The medium was changed every 3 days and after 15 days, the cells were fixed in a phosphate-buffered saline (PBS) solution, containing $0.2 \%$ glutaraldehyde and $0.5 \%$ formaldehyde, for $10 \mathrm{~min}$ on ice and stained with $0.2 \%$ crystal violet for $10 \mathrm{~min}$ at room temperature. The number of foci was counted. The experiments were performed in duplicate, and repeated at least twice.

\section{References}

Alcami A and Smith GL. (1995). J. Virol., 69, 4633-4639.

Alexopoulou L, Holt AC, Medzhitov M and Flavell RA. (2001). Nature, 413, 732-738.

Barber GN, Thompson S, Lee TG, Strom T, Jagus R, Darveau A and Katze G. (1994). Proc. Natl. Acad. Sci. USA, 91, 4278-4282.

Brandt TA and Jacobs BL. (2001). J. Virol., 75, 850-856.

Beattie E, Denzler KL, Tartaglia J, Perkus ME, Paoletti E and Jacobs BL. (1995). J. Virol., 69, 499-505.

Beattie E, Kauffman EB, Martinez H, Perkus ME, Jacobs BL, Paoletti E and Tartaglia J. (1996). Virus Genes, 12, 89-94.

Benkirane M, Neuveut C, Chun RF, Smith SM, Samuel CE, Gatignol A and Jeang KT. (1997). EMBO J., 16, 611-624.

Castelli JA, Hassel BA, Wood KA, Li XL, Amemiya K, Dalakas MC, Torrence P and Youle RJ. (1997). J. Exp. Med., 186, $967-972$.

Chang HW, Watson JC and Jacobs BL. (1992). Proc. Natl. Acad. Sci. USA, 89, 4825-4829.

Chong KL, Feng L, Schappert K, Meurs EF, Donahue TF, Friesen JD, Hovanessian AG and Williams BRG. (1992). EMBO J., 11, $1553-1562$.

Chu WM, Ostertag D, Li ZW, Chang L, Chen Y, Hu Y, Williams B, Perrault J and Karin M. (1999). Immunity, 11, $721-731$.

Clemens MJ and Elia A. (1997). J. Interferon Cytokine Res., $17,503-524$.

\section{Soft agar assay}

$10^{4}$ cells were plated in DMEM plus $10 \% \mathrm{CS}$ in $0.35 \%$ agar above a layer of $0.7 \%$ agar. After 3 weeks colonies were visualized and counted with the help of a microscope.

\section{RNase protection assay}

RNase protection assays were performed using a Riboquant Multiprobe RNase-protection Assay System mCYC-1an in vitro transcription kit and a RPA kit (Pharmingen). Reactions were performed following the standard protocol provided by the manufacturer. Purified DNase-treated total RNA (10 $\mu \mathrm{g}$ per reaction) was incubated with in vitrotranscribed radioactive ${ }^{32} \mathrm{P}$-labeled probe for $16 \mathrm{~h}$ at $56^{\circ} \mathrm{C}$ and then treated for $15 \mathrm{~min}$ at $37^{\circ} \mathrm{C}$, with RNaseA-RNaseT mix for $45 \mathrm{~min}$ at $30^{\circ} \mathrm{C}$. Residual RNase was digested by proteinase $\mathrm{K}\left(15 \mathrm{~min}\right.$ at $\left.37^{\circ} \mathrm{C}\right)$, and protected fragment were precipitated with $75 \%$ ethanol-4 $\mathrm{M}$ ammonium acetate for $16 \mathrm{~h}$ at $-70^{\circ} \mathrm{C}$. RNA pellets were dissolved in $8 \mu \mathrm{l}$ of loading buffer and $4 \mu \mathrm{l}$ was loaded on $5 \%$ denaturing polyacrylamide gels. Bands in dried gels were visualized on film and signals quantified using a STORM Phosphorimager (Molecular Dynamics, Sunnyvale).

\section{Acknowledgements}

We recognize Bertram L Jacobs (Arizona State University, AZ, USA) for the generous gift of the E3L antibody. We are grateful to Marcos Malumbres and Rocio Sotillo for helpful comments on transformation assays. We thank Don Roth for revision of the manuscript. This investigation was supported by research grants BIO2001-2269 of Spain and EU (BIO4-CT98-0456). MA García and J Gil were supported by fellowships from Ministerio de Ciencia y Tecnología, Spain.

Cuddihy AR, Li S, Tam NWN, Wong AH, Taya Y, Abraham N, Bell JC and Koromilas AE. (1999a). Mol. Cell. Biol., 19, $2475-2484$.

Cuddihy AR, Wong AH, Tam NWN, Li S and Koromilas AE. (1999b). Oncogene, 18, 2690-2702.

Davies MV, Chang HW, Jacobs BL and Kaufman RJ. (1993). J. Virol., 67, 1688-1692.

Der SD, Yang Y, Weissmann C and Williams BRG. (1997). Proc. Natl. Acad. Sci. USA, 94, 3279-3283.

Der SD, Zhou A, Williams BR and Silverman RH. (1998). Proc. Natl. Acad. Sci. USA, 95, $15623-15628$.

Díaz-Guerra M, Rivas C and Esteban M. (1997). Virology, 236, $354-363$.

Gale Jr M, Kwieciszewski B, Dossett M, Nakao H and Katze MG. (1999). J. Virol., 73, 6506-6516.

Geiss G, Jin G, Guo J, Bumgarner R, Katze MG and Sen GC. (2001). J. Biol. Chem., 276, 30178-30182.

Ghosh S, Michael JM and Kopp EB. (1998). Annu. Rev. Immunol., 16, 225-260.

Guo J, Peters KL and Sen GC. (2000). Virology, 267, $209-$ 219.

Heylbroeck C, Balachandran S, Servant MJ, DeLuca C, Barber GN, Lin R and Hiscott J. (2000). J. Virol., 74, $3781-3792$.

Jacobs BL and JO Langland. (1996). Virology, 219, $339-$ 349. 
Jagus R, Joshi B and Barber GN. (1999). Int. J. Biochem. Cell. Biol., 31, 175-189.

Kibler KV, Shors T, Perkins KB, Zeman CC, Banaszak MP, Biesterfeldt J, Langland JO and Jacobs BL. (1997). J. Virol., 71, $1992-2003$.

Kim T, Kim TY, Song Y, Min JM, Jim J and Kim TK. (1999). J. Biol. Chem., 43, 30686-30689.

Koromilas AE, Roy S, Barber GN, Katze MG and Sonenberg N. (1992). Science, 257, 1685-1689.

Kumar A, Yang Y, Flati V, Der S, Kadereit S, Deb A, Haque J, Reis L, Weismann C and Williams BRG. (1997). EMBO J., 16, 406-416.

Lee SB and Esteban M. (1993). Virology, 193, 1037-1041.

Lee SB and Esteban M. (1994). Virology, 199, 491-496.

Lee SB, Bablanian R and Esteban M. (1996). J. Interferon Cytokine Res., 16, 1073-1078.

Levin D and London IM. (1978). Proc. Natl. Acad. Sci. USA, 75, $1121-1125$.

Lu Y, Wambach M, Katze MG and Krug RM. (1995). Virology, 214, $222-228$.

Meurs EF, Chong K, Galabru J, Thomas NS, Kerr IM, Williams BR and Hovanessian AG. (1990). Proc. Natl. Acad. Sci. USA, 90, 232-236.

Meurs EF, Galabru J, Barber GN, Katze MG and Hovanessian AG. (1993). Cell, 62, 379-390.

Murcia-Nicolas A, Bolbach G, Blais JC and Beaud G. (1999). Virus Res., 59, $1-12$.

Paez E and Esteban M. (1984). Virology, 134, 12-28.

Park H, Davies MV, Langland JO, Chang HW, Nam YS, Tartaglia J, Paoletti E, Jacobs BL, Kaufman RJ and Venkatesan S. (1994). Proc. Natl. Acad. Sci. USA, 11, $4713-4717$

Petryshyn R, Chen JJ and London IM. (1984). J. Biol. Chem., 259, $14736-14742$.

Rebouillat D and Hovanessian AG. (1999). J. Interferon Cytokine Res., 19, 295-308.

Rivas C, Gil J, Melkova Z, Esteban M and Diaz-Guerra M. (1998). Virology, 243, 406-414.

Romano PR, Zhang F, Tan SL, Garcia-Barrio MT, Katze MG, Dever TE and Hinnebusch AG. (1998). Mol. Cell. Biol., 18, 7304-7316.

Sangfelt O, Erickson S, Castro J, Heiden T, Gustafsson A, Einhorn S and Grander D. (1999). Oncogene, 18, 2798 2810 .
Sen GC and Lengyel P. (1992). J. Biol. Chem., 267, $5017-$ 5020.

Sharp TV, Moonan F, Romashko A, Joshi B, Barber GN and Jagus R. (1998). Virology, 250, 302-315.

Sherr CJ. (1994). Cell, 79, 551-555.

Sherr CJ and Roberts JM. (1995). Genes Dev., 9, 1149-1163.

Smith EJ, Marié I, Prakash A, Garcia-Sastre A and Levy DE. (2001). J. Biol. Chem., 276, 8951-8957.

Smith GL. (1994). Trends Microbiol., 2, 81-88.

Smith GL, Symons JA, Khanna A, Vanderplasschen A and Alcami A. (1997). Immunol. Rev., 159, 137-154.

Srivastava SP, Kumar KU and Kaufman RJ. (1998). J. Biol. Chem., 273, 2416-2423.

Stark GR, Kerr IM, Williams BRG, Silverman RH and Schreiber RD. (1998). Annu. Rev. Biochem., 67, 227-264.

Symons JA, Alcami A and Smith GL. (1995). Cell, 81, $551-$ 560.

Tan SL and Katze MG. (1999). J. Interferon Cytokine Res., 19, $543-554$.

Tang NM, Korth MJ, Gale Jr M, Wambach M, Der SD, Bandyopadhyay SK, Williams BR and Katze MG. (1999). Mol. Cell. Biol., 19, 4757-4765.

Watson JC, Chang HW and Jacobs BL. (1991). Virology, 185, 206-216.

Williams BRG. (1999). Oncogene, 18, 6112-6120.

Xiang Y, Condit RC, Vijaysris S, Jacobs B, Williams BR and Silverman RH. (2002). J. Virol., 76, $5251-5259$.

$\mathrm{Xu}$ B, Kim ST, Kim DS and Kastan MB. (2002). Mol. Cell. Biol., 22, 1049-1059.

Yang YL, Reis LFL, Pavlovic J, Aguzzi A, Schafer R, Kumar A, Williams BRG and Weissmann C. (1995). EMBO J., 14, 6095-6106.

Yuwen H, Cox JH, Yewdell JW, Bennink JR and Moss B. (1993). Virology, 195, $732-744$.

Zhou A, Paranjape J, Brown TL, Nie H, Naik S, Dong B, Chang A, Trapp B, Fairchild R, Colmenares C and Silverman RH. (1997). EMBO J., 16, 6355-6363.

Zhou A, Paranjape JM, Der SD, Williams BR and Silverman RH. (1998). Virology, 258, $435-440$. 